\title{
The Effect of Quantity and Quality of Food Proteins on the Regeneration of Liver Protein in Protein-Depleted Rats
}

\author{
By K. GUGGENHEIM AND EDITH BUECHLER-CZACZKES \\ Laboratory of Nutrition, Hebrew University-Hadassah Medical School, ferusalem
}

(Received 10 March 1950)

During a fast or on a protein-free diet the liver loses more protein than any other organ in the animal body (Addis, Poo \& Lew, 1936a-c). This pronounced sensitivity of the liver to protein deprivation is paralleled by the rapid regeneration of liver protein (Addis et al. 1936a; Campbell \& Kosterlitz, 1948). Harrison \& Long (1945) have used regeneration of liver protein following a $48 \mathrm{hr}$. fast as a means of measuring the nutritional adequacy of gelatin, zein, gliadin, casein, and lactalbumin. By the use of their method they showed that the addition of methionine or cystine to a diet containing an inadequate amount of casein increases significantly the amount of liver protein regenerated after fasting. Vars \& Gurd $(1947 a, b)$ subjected rats to a period of 14 days on a non-protein diet, followed by ' $69.4 \%$ hepatectomy'. Various protein-containing diets were then offered. 'The regeneration of liver protein was found to be correlated with the quality as well as quantity of the food protein. Campbell \& Kosterlitz (1948) have shown that the amount of labile cytoplasm present in the liver depends on the quantity and quality of dietary protein.

The present paper reports experiments with protein-depleted rats, designed to determine: (I) the effect of various levels of dietary protein on the regeneration of liver protein; (2) the specific effects of various food proteins on the regeneration of liver protein.

\section{METHODS}

Male rats after weaning were fed on a protein-free diet, consisting of: starch $9 \mathrm{I}$ g., olive oil $5 \mathrm{~g}$., salt mixture $4 \mathrm{~g}$. The following were added to each $100 \mathrm{~g}$. of the diet: aneurin hydrochloride $0.1 \mathrm{mg}$., riboflavin $0.2 \mathrm{mg}$., pyridoxin $0.1 \mathrm{mg}$., calcium pantothenate $1.6 \mathrm{mg}$., nicotinic acid $5.0 \mathrm{mg}$., folic acid $0.25 \mathrm{mg}$., choline chloride roo mg. Each rat received roo i.u. vitamin A and 4 i.u. vitamin D twice weekly. After I week on this diet the animals were transferred to the various test diets.

In order to test the effect of different levels of dietary protein the diets listed below were used:

\begin{tabular}{|c|c|c|c|c|}
\hline & \multicolumn{4}{|c|}{ Diet } \\
\hline & $\mathrm{C}_{\mathrm{I}}$ & $\mathrm{C}_{2}$ & $\mathrm{C}_{3}$ & $\mathrm{C}_{4}$ \\
\hline $\begin{array}{l}\text { Casein }(\%) \\
\text { Rice starch (\%) }\end{array}$ & $\begin{array}{r}5.4 \\
85.6\end{array}$ & $\begin{array}{l}10 \cdot 8 \\
80 \cdot 2\end{array}$ & $\begin{array}{l}16.2 \\
74 \cdot 8\end{array}$ & $\begin{array}{l}32 \cdot 4 \\
58 \cdot 6\end{array}$ \\
\hline Olive oil $(\%)$ & $5 \cdot 0$ & $5 \cdot 0$ & $5 \cdot 0$ & $5 \cdot 0$ \\
\hline Salt mixture (\%) & $4 \cdot 0$ & 4.0 & $4^{\circ} 0$ & $4 \cdot 0$ \\
\hline Protein (\%) & 4.5 & $9 \cdot 0$ & 13.5 & $27 \cdot 0$ \\
\hline
\end{tabular}

These diets were supplemented with vitamins in the same way as the protein-free diet. 
In the experiments designed to determine the relative nutritive value of various food proteins the following protein sources were used: egg powder, dried meat, casein, fish meal, processed soya-bean flour, peanut meal, maize flour, wheat flour (white, $70 \%$ extraction), gelatin. The fat of egg powder, dried meat, soya-bean flour and peanut meal was extracted. The various protein sources were incorporated in the protein-free basal diet by replacing an appropriate amount of starch, so as to make the protein content of each diet $9 \mathrm{~g}$./100 g. ration.

All diets were, therefore, isocaloric. They were given in equal amounts, $6 \mathrm{~g}$. $/ \mathrm{rat} / \mathrm{day}$. After 2, 3 and 4 days, respectively, on the test diets the animals were killed by exsanguination, and the nitrogen content of their livers was determined by the Kjeldahl method.

\section{RESULTS}

Effect of the protein-free diet on the nitrogen content of the liver

The nitrogen content of the livers of twenty-five normal and of fifty protein-depleted rats is shown in 'Table 1 .

Table I. Nitrogen content of livers of twenty-five normal and of fifty protein-depleted rats

$\begin{array}{clc}\text { Normal rats } & \text { Mean value (mg./g.) } & 32.5 \\ & s_{x} \text { (mg./g.) } & 4.4 \\ & s_{x} \text { (mg./g.) } & 0.88 \\ \text { Protein- } & \text { Mean value (mig./g.) } & 23.1 \\ \text { depleted rats } & s_{x} \text { (mg./g.) } & 2 \cdot 9 \\ & s_{\bar{x}} \text { (mg./g.) } & 0.41\end{array}$

As can be seen from Table $I$, I week on a protein-free diet resulted in an average decrease in liver nitrogen of $29 \%$. Our figures agree well with those of Harkness, Seifter, Novic \& Muntwyler (1949), i.e. $24.4 \mathrm{mg}$./g. for livers of protein-deficient rats and $34 \cdot \mathrm{I} \mathrm{mg}$. $/ \mathrm{g}$. for the controls. A loss of liver cytoplasm to a similar extent, $28 . \mathrm{I} \%$, after I week on a protein-free diet, has been reported by Kosterlitz (I 947).

The effect of various levels of dietary protein on the regeneration of liver protein

The amounts of liver nitrogen found in protein-depleted rats after the feeding of diets $\mathrm{C}_{1}, \mathrm{C}_{2}, \mathrm{C}_{3}$ or $\mathrm{C}_{4}$, are given in Table 2.

Table 2. Liver-nitrogen content of protein-depleted rats given for 2, 3 or 4 days diets containing various levels of casein

\begin{tabular}{|c|c|c|c|c|c|c|}
\hline \multirow[b]{2}{*}{ Diet" } & \multicolumn{2}{|r|}{2 days } & \multicolumn{2}{|c|}{3 days } & \multicolumn{2}{|r|}{4 days } \\
\hline & $\begin{array}{l}\text { No. of } \\
\text { rats }\end{array}$ & $\begin{array}{l}\text { Liver nitrogen } \dagger \\
\text { (mg./g.) }\end{array}$ & $\begin{array}{l}\text { No. of } \\
\text { rats }\end{array}$ & $\begin{array}{l}\text { Liver nitrogen } \dagger \\
\text { (mg./g.) }\end{array}$ & $\begin{array}{l}\text { No. of } \\
\text { rats }\end{array}$ & $\begin{array}{l}\text { Liver nitrogen } \dagger \\
\text { (mg./g.) }\end{array}$ \\
\hline $\mathrm{C}_{\mathrm{I}}$ & 18 & $25 \cdot 3 \pm 3 \cdot 1$ & 18 & $26 \cdot 8 \pm 4 \cdot 6$ & 17 & $25 \cdot 8 \pm 2 \cdot 7$ \\
\hline $\mathrm{C}_{2}$ & 15 & $28 \cdot 6 \pm 2 \cdot 6$ & 21 & $28 \cdot 7 \pm 2 \cdot 8$ & 17 & $33 \cdot 9 \pm 3 \cdot 1$ \\
\hline $\mathrm{C}_{3}$ & 17 & $29 \cdot 1 \pm 2 \cdot 5$ & 58 & $30 \cdot 3 \pm 2 \cdot 3$ & II & $32 \cdot 1 \pm 3 \cdot 0$ \\
\hline $\mathrm{C}_{4}$ & 16 & $30 \cdot 7 \pm 1 \cdot 3$ & 15 & $32 \cdot \circ \pm 2 \cdot 3$ & 15 & $3 \times \cdot 4 \pm 2 \cdot 9$ \\
\hline
\end{tabular}


It follows from Table 2 that the dietary levels of casein tested differed markedly in their effect on the regeneration of liver protein. $C_{\text {I }}$ did not raise the level of liver nitrogen above $26 \mathrm{mg}$./g. even after 4 days' feeding; $\mathrm{C}_{2}$ promoted a regeneration of liver protein to its normal level after 4 days. With higher dietary levels of casein a rapid and more or less complete regeneration after 3 or even 2 days' feeding was observed. In order to assess the relative efficiency of each protein level tested, the 'mean daily increase' (M.D.I.) in liver nitrogen over that found after protein depletion, $23.1 \mathrm{mg} . / \mathrm{g}$., was calculated for each protein level.

The method of calculating is illustrated in the following example: the figures for liver nitrogen for diet $\mathrm{C}_{3}$ after 2,3 and 4 days' feeding were $29^{\cdot} \cdot 1,30^{\circ} 3$ and $32^{\cdot} \cdot \mathrm{Img} . \mathrm{g}$. respectively. 'The mean values after 2,3 and 4 days' feeding were, therefore, $\frac{1}{3}\left(29^{\circ} \cdot 1+30 \cdot 3+32 \cdot 1\right)=30 \cdot 5$. Hence the mean daily increase, $\frac{1}{3}(30 \cdot 5-23 \cdot 1)=2 \cdot 47$. The following M.D.r. values were found for the four casein levels tested: $\mathrm{C}_{1}, 0.97$; $\mathrm{C}_{2}, 2.43 ; \mathrm{C}_{3}, 2.47 ; \mathrm{C}_{4}, 2.77$. They show that increasing the dietary level of casein above $9 \%$ did not markedly increase the M.D.I.

\section{The effect of various food proteins on the regeneration of liver protein}

The amounts of liver nitrogen found after feeding various food proteins to proteindepleted rats for 2,3 or 4 days, are given in Table 3 .

Table 3. Liver-nitrogen content of protein-depleted rats given for 2, 3 or 4 days various proteins at $9 \%$ level.

\begin{tabular}{|c|c|c|c|c|c|c|}
\hline \multirow[b]{2}{*}{$\begin{array}{c}\text { Source } \\
\text { of } \\
\text { protein }\end{array}$} & \multicolumn{2}{|r|}{2 days } & \multicolumn{2}{|c|}{3 days } & \multicolumn{2}{|r|}{4 days } \\
\hline & $\begin{array}{l}\text { No. of } \\
\text { rats }\end{array}$ & $\begin{array}{l}\text { Liver nitrogen } \\
\text { (mg./g.) }\end{array}$ & $\begin{array}{l}\text { No. of } \\
\text { rats }\end{array}$ & $\begin{array}{l}\text { Liver nitrogen } \\
\quad(\mathrm{mg} / \mathrm{g} .)\end{array}$ & $\begin{array}{l}\text { No. of } \\
\text { rats }\end{array}$ & $\begin{array}{l}\text { Liver nitrogen } \\
\quad \text { (mg./g.) }\end{array}$ \\
\hline Soya bean & 20 & $28 \cdot 6 \pm 2 \cdot 8$ & 20 & $31 \cdot 9 \pm 2 \cdot 5$ & 10 & $32 \cdot 3 \pm 2 \cdot 7$ \\
\hline Casein & 15 & $28 \cdot 6 \pm 2 \cdot 6$ & 21 & $28 \cdot 7 \pm 2 \cdot 8$ & 17 & $33 \cdot 9 \pm 3 \cdot 1$ \\
\hline Egg & I I & $27.6 \pm 2.5$ & II & $28 \cdot 6 \pm 3 \cdot 7$ & 12 & $34 \cdot 0 \pm 3 \cdot 3$ \\
\hline Meat & 17 & $26 \cdot 3 \pm 3 \cdot 6$ & II & $29 \cdot 3 \pm 2 \cdot 0$ & 18 & $33 \cdot 3 \pm 3 \cdot 3$ \\
\hline Peanut & II & $27 \cdot 1 \pm 2 \cdot 0$ & 12 & $28 \cdot 6 \pm r \cdot 8$ & 12 & $28 \cdot 3 \pm 2 \cdot 3$ \\
\hline Gelatin & I I & $25.4 \pm 1 \cdot 4$ & 12 & $27 \cdot 1 \pm 2 \cdot 0$ & 11 & $27 \cdot 7 \pm 1 \cdot 7$ \\
\hline Fish & 12 & $24 \cdot 9 \pm 3 \cdot I$ & I 5 & $28 \cdot 6 \pm 2 \cdot 2$ & 15 & $26 \cdot 6 \pm 1 \cdot 2$ \\
\hline Maize & I I & $24 \cdot 5 \pm 1 \cdot 4$ & 12 & $26 \cdot 6 \pm 4 \cdot 0$ & 10 & $27 \cdot 9 \pm 2 \cdot 6$ \\
\hline Wheat & 12 & $24 \cdot 8 \pm 2 \cdot 9$ & 12 & $25.1 \pm 2.9$ & I 2 & $24 \cdot 3 \pm 1 \cdot 8$ \\
\hline
\end{tabular}

Table 3 shows that the proteins tested differed markedly in their ability to form liver protein. Soya, egg, meat and casein ranked first; their feeding for 3 days at a $9 \%$ level resulted in complete regeneration of liver protein. The proteins of peanut, gelatin, fish and those of the cereals, maize and wheat, were considerably less efficient. It is noteworthy that the proteins tested regenerated liver protein at different rates. After 2 days only soya, fish and wheat proteins showed a maximal response; with the other proteins a further increase in liver protein could be observed on the 3 rd day of protein feeding.

Using the M.D.I. values as an index of the relative nutritional significance of the various food proteins the following order of nutritive values was obtained: soya $2 \cdot 60$, 
casein $2 \cdot 43$, egg $2 \cdot 33$, meat $2 \cdot 17$, peanut $I \cdot 63$, gelatine $I \cdot 20$, fish $I \cdot 20$, maize $1 \cdot 07$, wheat 0.53 .

These values show that $9 \%$ soya protein promoted better regeneration of liver protein than that obtained with $13.5 \%$ casein, whereas $9 \%$ maize protein increased the level of liver nitrogen not more than $4.5 \%$ casein.

\section{DISCUSSION}

The biological value of proteins is usually assessed either by the nitrogen-balance method or by the protein-efficiency ratio (g. gain in body-weight/g. protein consumed). Block \& Mitchell (1946) have demonstrated the close relationship existing between the results of these two procedures. 'I'hey have also shown that the nutritive value of each protein as assessed by these methods is correlated to the amino-acid composition of the respective protein. Campbell \& Kosterlitz (1948) suggested a new method for the assay of the nutritive value of proteins in adult rats. It is based on the fact that the amount of labile cytoplasm present in the liver depends on the quantity and quality of dietary protein. Labile liver cytoplasm was estimated by the above authors by determination of protein, phospholipin and nucleic acid, or of the non-glycogen non-lipid liver solids. Testing egg albumin, casein, whole wheat, white flour and soya-bean flour they found a close agreement between the values obtained by their methods and those obtained by the balance-sheet method. Vars $\&$ Gurd (1947b) studied the regeneration of liver substance after partial hepatectomy. The feeding of gelatin and zein did not give a greater degree of regeneration of liver protein than occurred on a non-protein diet. Wheat gluten and casein gave a moderate increase. Fibrin and egg protein gave a greater amount of new liver protein than casein at the same dietary level. Li (1936) reports that soya-bean protein gives as much storage of liver protein as animal proteins.

Our results indicate that the ability of a given protein to regenerate liver protein is not necessarily correlated with its biological value as determined by the two classical methods. Moreover, a comparison of the relative biological values of eight proteins as determined by five different procedures, i.e. protein-efficiency ratio, nitrogen-balance method, increase in liver protein and capacity to form haemoglobin and granulocytes in protein-depleted rats (Guggenheim \& Buechler, I949; Buechler \& Guggenheim, 1949) shows different orders of nutritive values (Table 4 ).

It follows from Table 4 that proteins may differ in their relative efficiency according to the method by which their value is assessed. Soya, the most efficient source of protein for the regeneration of liver protein, has a relatively low capacity for forming granulocytes. Egg proteins rank first in the formation of haemoglobin and granulocytes and in ability to promote growth and maintain nitrogen balance, but they are inferior to soya protein and casein for the regeneration of liver protein. Maize proteins are decidedly inferior to peanut proteins for growth efficiency and in formation of liver protein and of granulocytes, but are equally efficient in maintaining nitrogen balance and regenerating haemoglobin. Gelatin, the least efficient protein for maintaining nitrogen balance and forming haemoglobin, proved superior to the cereal proteins in regenerating liver protein. It follows, therefore, that an amino-acid composition that may be optimal for acceleration of growth and the maintenance of nitrogen balance 
Table 4. Comparison of nutritive ratings of protein by various procedures

(The figures for the nitrogen-balance method and the protein-efficiency ratio are taken from the review of Block \& Mitchell (1946); the figures for the capacity to form haemoglobin and granulocytes are based on previous publications from this laboratory (Buechler \& Guggenheim, 1949))

\begin{tabular}{|c|c|c|c|c|c|}
\hline \multirow{3}{*}{$\begin{array}{c}\text { Food } \\
\text { protein }\end{array}$} & \multirow{3}{*}{$\begin{array}{l}\text { Protein- } \\
\text { efficiency } \\
\text { ratio }\end{array}$} & \multirow{3}{*}{$\begin{array}{l}\text { Biological } \\
\text { value by } \\
\text { nitrogen- } \\
\text { balance } \\
\text { method }\end{array}$} & \multirow{2}{*}{$\begin{array}{l}\text { Mean daily } \\
\text { increase in } \\
\text { liver nitrogen } \\
\text { (M.D.I.) }\end{array}$} & \multicolumn{2}{|c|}{ Relative capacity to regenerate } \\
\hline & & & & Haemoglobin & Granulocytes \\
\hline & & & \multicolumn{3}{|c|}{ In protein-depleted rats } \\
\hline F.gg & $3 \cdot 8$ & 96 & $2 \cdot 33$ & 100 & 100 \\
\hline Meat & $3 \cdot 2$ & 76 & $2 \cdot 17$ & 92 & 99 \\
\hline Casein & $2 \cdot 0$ & 69 & $2 \cdot 43$ & 62 & 39 \\
\hline Soya bean & $2 \cdot 3$ & 75 & $2 \cdot 60$ & 83 & 45 \\
\hline Peanut & $1 \cdot 7$ & $5^{8}$ & $r \cdot 63$ & 54 & 47 \\
\hline Maize & $1 \cdot 2$ & 54 & $1 \cdot 07$ & 54 & 18 \\
\hline Wheat & $1 \cdot 0$ & 52 & 0.53 & 17 & 27 \\
\hline Gelatin & - & 25 & $1 \cdot 20$ & -21 & 26 \\
\hline
\end{tabular}

need not be optimal for other physiological functions of dietary protein. Different cell structures (liver cells, erythrocytes, granulocytes) seem to require proteins of different composition for optimal utilization.

\section{SUMMARY}

1. The increase of liver nitrogen in protein-depleted rats given casein at various dietary levels, or various food proteins at a $9 \%$ level, has been studied.

2. A diet containing $4.5 \%$ casein protein did not significantly raise the level of liver nitrogen. Double this concentration of casein promoted a regeneration of liver protein to its normal level after 4 days. Higher dietary levels of this protein induced a more or less complete regeneration after 2 or 3 days' feeding.

3. The ability of the proteins investigated to regenerate liver protein decreased in the following order: processed soya, casein, egg, meat, peanut, gelatin, fish, maize and wheat.

4. The relative nutritive value of various food proteins as assessed by several methods is discussed.

\section{REFERENCES}

Addis, T., Poo, L. J. \& Lew, W. (1936a). F. biol. Chem. rrg, I I I.

Addis, T., Poo, L. J. \& Lew, W. $(1936 b)$. F. biol. Chem. $115,117$.

Addis, T., Poo, L. J. \& Lew, W. (1936c). Y. biol. Chem. I16, 343.

Block, R. J. \& Mitchell, H. H. (1946). Nutr. Abstr. Rev. 16, 249.

Buechler, E. \& Guggenheim, K. (1949). Blood, 4, 964.

Campbell, R. M. \& Kosterlitz, H. W. (1948). F. Physiol. 107, 383.

Guggenheim, K. \& Buechler, E. (1949). Blood, 4, 958.

Harkness, D. M., Seifter, S., Novic, B. \& Muntwyler, E. (1949). Arch. Biochem. $22,204$.

Harrison, H. C. \& Long, C. N. H. (r945). F. biol. Chem. 16r, 545.

Kosterlitz, H. W. (1947). \%. Physiol. ro6, 194.

Li, H.-M. (1936). Chin. F. Physiol. ro, 7.

Vars, H. M. \& Gurd, F. N. (1947a). Amer. F. Physiol. 15r, 39 I.

Vars, H. M. \& Gurd, F. N. (1947b). Amer. F. Physiol. 151, 399. 